\title{
O "Júri" Alemão \\ O leigo no processo penal na Alemanha
}

\author{
The German "jury". \\ The layman in the Criminal Procedure of Germany
}

\section{Uriel Moeller}

Doutorando em Direito pela Universität Osnabrück (Alemanha) e pelo Programa de Pós-Graduação em Ciências Criminais da PUCRS em co-tutela ${ }^{1}$ uriel.moeller@uos.de

Resumo: O presente artigo oferece uma visão geral do papel do juiz leigo no sistema penal alemão, bem como apresenta os respectivos direitos e funções, em comparação ao júri brasileiro. Além disso, exalta a importância de uma instituição que aumenta a conscientização no sistema penal enquanto evita posições que romantizam demasiadamente o papel do leigo no processo penal.

Palavras-chave: Júri, Juiz Leigo, Schöffe, Processo Penal, Alemanha, Brasil, Sistema Jurídico

AвSTRACT: This article gives an overview of the role, rights and function of the lay judge in the German criminal law system, drawing comparisons with the Brazilian jury. The author defends an institution that heightens consciousness in the criminal law system, while avoiding to side with over romanticized positions defending laymen in the criminal procedure.

Keywords: Jury, Lay judge, Schöffe, Criminal Procedure, Germany, Brazil, Legal System

1 Especialista em Direito Internacional e Europeu (Wablschwerpunkt). Staatsexamen Hamburgo 2013. Assistente de pesquisa (Wissenschaftlicher Mitarbeiter) no projeto ALPhA na Universidade de Osnabrück (Bolsista CAPES). E-mail: uriel. moeller@uos.de. Agradeço aos colegas e aos professores da PUCRS pelo apoio no desenvolvimento deste artigo, especialmente ao colega Bruno Buonicore, ao professor Nereu José Giacomolli e ao professor Fabio Roberto D’Avila. 


\section{INTRODUÇÃO}

A participação de pessoas leigas no processo penal ${ }^{2}$ é prevista em muitos países de cultura, história e tradição jurídica bastante diversas. ${ }^{3}$ Não surpreende, portanto, que estas diferenças se concretizem em concepções, previsões e regulamentos divergentes em países diferentes. Frequentemente, isso é motivo de mal-entendidos sobre os direitos e os poderes dos leigos que atuam nos processos penais dos respectivos países, assumindo-se equivalências onde não há. Para evitar tais confusões, iremos expor o sistema de participação leiga no processo penal alemão. Na Alemanha, um juízo de condenação ou absolvição pode depender de uma decisão dos leigos, como ocorre no caso do júri brasileiro? ${ }^{4}$ No famoso caso do "canibal de Rothenburg", alguns "jurados" na Alemanha teriam ficado confusos com o fato de o canibalismo não ser punível pela lei alemã. ${ }^{5}$ Qual seria a importância desse fato para o julgamento?

2 Este artigo não tratará da participação de leigos em outros processos, assim como não tratará das exceções que se aplicam ao processo penal de jovens (14 a 18/21 anos), § 1 Jugendgerichtsgesetz (JGG).

3 Ver sobre seu desenvolvimento na França, na Alemanha, na Inglaterra, em Roma e na antiga Grécia: DAWSON, John P. A History of Lay Judges. Cambridge, Massachusetts: HARVARD UNIVERSITY PRESS, 2010 (1960). No sistema alemão, desenvolvido a partir do sistema inquisitório, porém, pode ser considerada uma reintrodução resultando da revolução francesa: DUTTGE, Gunnar. Laienrichter in der Strafgerichtsbarkeit - Anspruch und Wirklichkeit. Juristische Rundschau, Heft 9/2006, p. 358; SATZGER, Helmut. Die Schöffen im Strafprozess. Juristische Ausbildung, Heft 7/2011, p. 518, p. 519; VOLK, Klaus. GRUNDKURS StPO. München: Verlag C.H. Beck,2008, p. 14 (§ 5, 15); BÖRNER, René. Die Beteiligung von Laienrichtern am Strafprozess als Erkenntnismittel einer funktionellen Theorie des Strafprozessrechts. Strafverteidiger Forum, 11/2012, p. 434, p. 436.

4 Através do questionário, art. 482 ss. Código de Processo Penal (CPP). Devido ao espaço restrito de um artigo, não compararemos ao juiz leigo brasileiro previsto no juizado especial criminal pelo artigo 60 da lei 9.099/95, que julgaria somente contravenções penais e crimes com pena máxima de dois anos (art. 61 da referente lei).

5 Situação descrita por SANDEL, Michael J. Justiça - O que é fazer a coisa certa. Rio de Janeiro: Civilização Brasileira, 2012, p. 94. 
Essas questões serão esclarecidas posteriormente, ${ }^{6}$ porém passamos, já neste ponto, a introduzir a terminologia alemã. $\mathrm{O}$ juiz leigo no sistema penal contemporâneo alemão se chama "Schöffe". 7 A origem etimológica da palavra não é pacífica, mas a descendência da palavra "scabini", possivelmente relaciona-se com a terminologia portuguesa para este sistema de participação leiga, o escabinato. ${ }^{9}$ Este artigo visa, em um primeiro momento, explicar quem é a pessoa do Schöffe, para depois discutir sua funcionalidade e sua legitimidade no sistema processual penal, também, levando em consideração a discussão de tais aspectos no sistema brasileiro. Para entendermos como funciona a participação de leigos no sistema penal alemão é fundamental entender como o Schöffe é eleito (2.) qual é o seu âmbito de competência (3.) e qual é o seu papel (4.). Apos resumirmos a situação do Schöffe no processo penal alemão (5.), apontaremos algumas criticas da participação leiga (6.) e ofereceremos uma conclusão (7.).

\section{A ELEIÇÃo do SCHÖFFE}

O Schöffe não é escolhido aleatoriamente na população alemã. Existe um processo regulamentado por lei que determina como o cidadão deve ser eleito para o cargo e quais são as qualidades mínimas para assumi-lo. Como exemplo dos problemas que podem surgir a partir desse processo, existe um caso de alegada inidoneidade para o cargo de Schöffe que recentemente criou polêmica na Alemanha. Esse caso será discutido nesse trabalho (2.3).

6 Como parte do resumo na parte 5 do presente artigo.

7 Terminologia decretada por $\S 45$ a Deutsches Richtergesetz (DRiG). O termo para juízas leigas, segundo a gramática alemã, é "Schöffin".

8 Origem etimológica de Schöffe: do antigo alemão "skephen", ordenar, dar forma - http://de.wiktionary.org/wiki/Schöffe. Segundo DAWSON, John P. A History of Lay Judges..., p. 94, mais especificamente do "scabini", juiz leigo da dinastia carolíngia.

9 Ver sobre o escabinato entre outros VASCONCELLOS, Vinicius Gomes de; GALÍCIA, Caíque Ribeiro. Tribunal do júri na justiça criminal brasileira: críticas e propostas de reforma para a restituição de sua função de garantia no processo penal democrático. Revista Eletrônica de Direito Processual, 2014, volume 13, p. 903. 


\subsection{Processo de eleição}

Vejamos, então, qual é o processo e quais são as consequências da infração às normas regulamentadoras. Em um processo guiado pelos dispositivos dos $\S \S 36$ ss. da Gerichtsverfassungsgesetz (GVG), ${ }^{10} \mathrm{o}$ Schöffe é eleito por cinco anos. ${ }^{11} \mathrm{O}$ município (Gemeinde) cria, no quinto e último ano do período de exercício da função de Schöffe, uma lista de sugestão com nomes de candidatos para o cargo para o próximo período. ${ }^{12}$ Essa lista é elaborada livremente, ${ }^{13}$ mas deve representar todos os grupos da sociedade, considerando sexo, idade, profissão e nível social. ${ }^{14}$ O cidadão pode se candidatar para esta lista. ${ }^{15} \mathrm{~A}$ lista de sugestão, ao ser concluída, é exibida no município por uma semana, ${ }^{16}$ período em que é possível fazer objeção aos candidatos. ${ }^{17}$ Esta lista, constando possíveis

10 "Gerichtsverfassungsgesetz" significa lei da constituição dos tribunais.

$11 \S 42$ I Nr. 1 GVG.

$12 \S 36$ I GVG. Dois terços dos representantes presentes do município, e no mínimo a metade de todos os representantes legais da comunidade, devem estar a favor da eleição do candidato para a lista.

${ }^{13}$ Um sorteio, por outro lado, não é permitido, por infringir grave e manifestamente o procedimento de elaboração da lista: SATZGER, Helmut. Die Schöffen im Strafprozess..., p. 522. Ver também nota de rodapé 24.

14 § 36 II GVG.

15 Assim estaria se auto-sugerindo para fazer parte da lista de sugestão. Isto foi facilitado para o período mais recente, que começou em 2013, por um site de internet: http://www.schoeffenwahl.de/interessenten/ (acessado em 04.12.2013).

$16 \S 36$ III, IV GVG. Nela deve constar, no mínimo, o dobro de pessoas exigidas pelo presidente do Landgericht (segunda instância em casos de crimes "leves", primeira em casos de crimes "graves" - ver sobre isto mais abaixo, no item 2.3), nos termos do $\S 43$ GVG. Assim, substituições serão possíveis, "Hilfsschöffen" (§ 42 I Nr. 2 GVG), e isto também durante o processo através do "Ergänzungsschöffen". Ver: SATZGER, Helmut. Die Schöffen im Strafprozess..., p. 526. No Brasil, há regulamento semelhante a este último, considerando no mínimo 15 jurados presentes para o julgamento (art. 463 $\mathrm{CPP}$ ), possibilitando então a exclusão de jurados sem perder a viabilidade do julgamento (art. 463 § $2 \mathrm{CPP}$ ), que depende do sorteio de somente sete jurados para o conselho de sentença (art. $467 \mathrm{CPP})$.

$17 \S 37$ GVG. 
objeções (por exemplo, inelegibilidade - ver no próximo parágrafo) é enviada para o Amtsgericht (AG, tribunal de "primeira instância", ver mais abaixo parte 3.a) do distrito. ${ }^{18}$ No Amtsgericht há uma comissão constituída por um juiz, um funcionário público e mais sete pessoas de confiança ${ }^{19}$, que decidem sobre as objeções. ${ }^{20}$ Entre os candidatos restantes da lista de sugestão, a comissão elege os Schöffen para os próximos cinco anos, reconsiderando a sua representatividade. ${ }^{21}$

Porém, sentenças proferidas com a participação de Schöffen que foram eleitos em procedimentos que não atenderam às normas referentes à lista de sugestão, não podem ser reformadas com base nesse fundamento. Somente se a comissão, no Amtsgericht, não estiver constituída corretamente e, portanto, não houver eleição eficaz, as decisões tomadas com a participação dos Schöffen eleitos sob infração ao procedimento justificariam a Revision (instituto semelhante à revisão criminal). ${ }^{22}$ Mesmo neste caso, atendendo ao princípio da segurança jurídica, somente erros graves e manifestos na constituição da comissão justificariam uma Revision. ${ }^{23}$ Outras infrações contra o procedimento da eleição, da mesma forma, só serão relevantes para os julgamentos se forem graves e manifestas, verbi gratia, a eleição de cidadão que não constava na lista. ${ }^{24}$

\subsection{QualidAdes MÍNIMAS PARA A ELEIÇão}

As características do juiz leigo na Alemanha são reguladas de forma mais detalhada do que no Brasil, onde o cidadão deve ser maior

$18 \S 38$ GVG.

19 Estes são eleitos pelo distrito de forma semelhante à eleição dos candidatos à lista elaborada pelo município ( $\$ 40 \mathrm{GVG}$ ).

$20 \S \S 40,41 \mathrm{GVG}$.

$21 \S 42$ GVG.

22 Bundesgerichtshof(BGH): Beschluss vom 16.07.2008 - 2 StR 83/08.

23 SATZGER, Helmut. Die Schöffen im Strafprozess..., p. 522.

24 Sobre este ponto, ver ainda: GERICKE, Jan. Karlsruber Kommentar zur Strafprozessordnung. München: Verlag C. H. Beck, 7. Auflage 2013, § 338 StPO, n 39-47; SATZGER, Helmut. Die Schöffen im Strafprozess..., p. 522. 
de 18 anos e ter "notória idoneidade" (art. 436 do Código de Processo Penal - CPP). Na Alemanha o candidato deve ser, em primeiro momento, elegível e, em segundo lugar, capacitado para o cargo de Schöffe. ${ }^{25}$ Enquanto a cidadania alemã é o critério positivo de elegibilidade (ver $\S$ $31 \mathrm{GVG}),{ }^{26}$ os outros critérios são negativos, definindo várias qualidades que impedem a atuação como Schöffe. Nos termos dos $§ 33$ Nr. 1-6 GVG, não deve ser nominado como Schöffe quem:

a. estiver com menos de 25 anos ou tiver alcançado 70 anos de idade;

b. residir em município diferente ao da sede do tribunal onde atua;

c. não apresentar condições suficientes de saúde para seguir o processo ou domínio suficiente da língua alemã ${ }^{27}$;

d. estiver em uma situação de deterioração do seu patrimônio.

Entre a população restante também não pode ser Schöffe quem for funcionário do Ministério Público, juiz, advogado, tabelião, policial e alguns outros tipos de funcionários do aparelho legal, ${ }^{28}$ regulamento previsto também no art. $437 \mathrm{CPP}$, que prevê semelhante isenção. Os eleitos têm o dever de assumir os seus cargos, limitando a sua dispensa para poucos casos previstos na lei, quando requerida pelo eleito. ${ }^{29} \mathrm{O}$ Schöffe eleito presta juramento ${ }^{30}$ e é obrigado a preencher seu cargo sob

25 Sobre previsões acerca da pessoa do Schöffe, ver mais detalhadamente: SATZGER, Helmut. Die Schöffen im Strafprozess..., p. 521 ss.

${ }^{26}$ Múltipla cidadania não veda esta qualidade: SATZGER, Helmut. Die Schöffen im Strafprozess..., p. 520 s.

${ }^{27}$ Uma decisão em que a falta de domínio da língua alemã resultou em Revision bem sucedida: BGH, Urteil vom 26. 1. 2011 - 2 StR 338/10 (LG Köln).

$\S 34$ I Nr. 1-7 GVG. Esta norma prevê ainda mais exceções, por exemplo, para o presidente da República e ministros, padres e outros líderes religiosos etc.

29 § 35 GVG: no caso de médicos ou enfermeiros, pessoa idosa, deputado, pessoa que já exerceu o cargo anteriormente etc.

30 Nos termos do $\$ 45$ III-V Deutsches Richtergesetz (DRiG). Falta do mesmo constitui "base absoluta" para a Revision: SATZGER, Helmut. Die Schöffen im Strafprozess..., p. 522. 
pena de sanção financeira ( $\$ 56 \mathrm{GVG}),{ }^{31}$ o que ocorre também no Brasil (art. 436 § $2 \mathrm{CPP}$ - recusa - e art. $442 \mathrm{CPP}$ - ausência). Por outro lado, sua atuação e suas despesas são restituídas nos termos do § 55 GVG remetendo aos $\S \S 15$ ss. Justizvergütungs-und-entschädigungsgesetz (JVEG), com $6 €$ até $24 €$ por hora. ${ }^{32}$

Se um Schöffe inelegivel for eleito e participar de um processo, isto per se não justifica recurso contra a decisão de que ele participou. ${ }^{33}$ Por sua vez, no caso de participação do Schöffe incapacitado, estamos diante de uma infração do princípio do juiz natural, o que em si já justifica a Revision. ${ }^{34} \mathrm{~A}$ incapacidade do cidadão de ser eleito como Schöffe dá-se nos termos do $§ 32 \mathrm{GVG}$ quando o mesmo:

a. perde a sua capacidade de exercer um cargo público por decisão judicial;

b. foi condenado a uma pena de prisão ou detenção de no mínimo seis meses por um crime doloso;

c. estiver sendo investigado por um crime que pode resultar em perda da capacidade de exercer um cargo público.

Outro impedimento é ter infringido os princípios de humanidade e do Estado de direito ( $\$$ 44a I Nr. 1 Deutsches Richtergesetz -DRiG, “Lei alemã dos juízes”) ${ }^{35}$.

31 Inclusive os custos causados pelo não cumprimento dos deveres do seu cargo (§ 56 I GVG). Exceção: § 54 GVG.

326 € pelo tempo investido ( $§ 16 \mathrm{JVEG}$ ) e até $24 €$ a mais pelas perdas econômicas causadas por sua ausência no seu serviço (§ 18 JVEG). Caso o processo demore mais que 50 sessões nas quais o Schöffe atuou, este valor restitutivo pode aumentar até o valor máximo de $61 €$ por hora $(\S 18 \mathrm{~S} .3$ JVEG). Transporte e algumas outras despesas também são restituídas ( $\$ 15$ JVEG). O § 45 Ia DRiG estipula que o Schöffe não pode sofrer discriminação, especialmente trabalhista, por causa da sua função. A norma mais próxima no sistema brasileiro parece ser o art. $441 \mathrm{CPP}$.

33 SATZGER, Helmut. Die Schöffen im Strafprozess..., p. 521.

34 SATZGER, Helmut. Die Schöffen im Strafprozess..., p. 520.

35 Explicitamente não pode ser Schöffe quem trabalhou pelo serviço de inteligência da Alemanha Oriental (Stasi) (§ 44a I Nr. 2 DRiG). 


\subsection{A VeSTIMENTA RELIGIOSA COMO IMPEDIMENTO PARA A ATUAÇÃO DO SCHÖFFE}

O Schöffe deve ser leal à constituição ( $§ 45$ III DRiG), ${ }^{36}$ e o cargo de juiz também demanda, leigo ou não, neutralidade e imparcialidade. ${ }^{37}$ Tais características foram consideradas ausentes em uma Schöffin que usava véu muçulmano, resultando na exclusão da cidadã como Schöffin do caso. ${ }^{38}$ A fundamentação desta decisão utilizou palavras como "imparcialidade" e "dignidade do tribunal". Optar por um véu e usar o mesmo durante a atuação como Schöffe demonstraria uma certa visão de mundo (Weltanschauung) rígida, especialmente em relação ao papel da mulher, restringindo-o religiosamente. ${ }^{39}$ A Schöffin, assim, demonstraria que sua decisão seria tomada a partir desta sua visão e não atendendo à lei, que é o papel do juiz nos termos do Art. 20 II, 97 I Grundgesetz (GG, Constituição alemã).

Este raciocínio foi rejeitado por muitas vozes da doutrina e da jurisprudência. ${ }^{40} \mathrm{O} \S 34 \mathrm{I}$ Nr. 6 GVG, a única norma de inelegibilidade como Schöffe com referência à religião, exprime: os sacerdotes e outros

${ }^{36}$ Em nível constitucional, isto se dá a partir do Art. 92 e 20 II GG, como o Bundesverfassungsgericht (BVerfG, "Tribunal Constitucional Federal”) decidiu para os juízes leigos no processo trabalhista (BVerfG, Beschluss vom 6. 5.2008 - 2 BvR 337/08). Sobre aplicação para os Schöffen ver: ANGER, Thorsten. Die Verfassungstreuepflicht der Schöffen. Neue Juristische Wochenschrift, 2008, p. 3041; SATZGER, Helmut. Die Schöffen im Strafprozess..., p. 525.

37 BADER, Johann. Die Kopftuch tragende Schöffin. Neue Juristische Wochenschrift, 2007, p. 2964.

38 LG (Landgericht) Dortmund. Neue Juristische Wochenschrift 2007, p. 3013 (LG Dortmund, Beschluß vom 7. 11.2006 - 14 (VIII) Gen. Str. K.).

39 "Das Kopftuch verkörpert eine strenge weltanschauliche Haltung, die sich unter anderem auf die Stellung der Frau in der Gesellschaft und der Öffentlichkeit bezieht und Ausprägung einer religiösen Einschränkung dieser Stellung ist", ver fundamentação: LG (Landgericht) Dortmund. Neue Juristische Wochenschrift 2007, p. 3014.

40 BADER, Johann. Die Kopftuch tragende Schöffin..., p. 2964 e 2966; SATZGER, Helmut. Die Schöffen im Strafprozess..., p. 525; LG Bielefeld: Beschluss vom 16.03.2006 - 3221 b EH 68; KG, Urteil vom 09.10.2012 - (3) 121 Ss 166/12 (120/12); GROH, Kathrin. Angewandte Verfassungsrechtsprechung? - Die Schöffin mit Kopftuch. Neue Zeitschrift für Verwaltungsrecht, 2006, p. 1023, p. 1026. 
líderes religiosos estão excluídos de exercer o cargo do Schöffe ${ }^{41}$ Segundo Satzger $^{42}$, isto permitiria dizer, argumentum e contrario, que o mero membro de uma comunidade religiosa não pode ser excluído somente por esta sua característica. Ademais segundo Bader, ${ }^{43}$ poderíamos concluir, já que líderes religiosos costumam se vestir de forma que ostentaria a sua religiosidade, que a inelegibilidade dos mesmos, através da norma especial do § 34 I Nr. 6 GVG, significaria que o legislador considera que, pelas normas gerais, a saber, o princípio da neutralidade do juiz, uma exclusão não pode ser realizada com base na vestimenta religiosa.

Os dois argumentos, porém, não são, por si só, convincentes. $\mathrm{O}$ argumentum e contrario de Satzger nada diz sobre a vestimenta, mas somente sobre ser membro de uma comunidade religiosa. Que isto constitucionalmente não pode ser motivo de exclusão é evidente por motivos de liberdade religiosa (art. 4 I, II GG) e até mesmo de discriminação (art. 3 I, III GG). ${ }^{44}$ Mas o caso aqui é de um Schöffe se vestire julgar com vestimenta religiosa.

O Argumento de Bader de que a existência da lei específica ( $\$ 34$ I Nr. 6 GVG) comprovaria que, sem ela, a norma geral - o princípio da neutralidade do juiz - não permite exclusão do líder religioso - e em consequência não permite a exclusão de membros de comunidade religiosa que usem trajes religiosos - é um argumento mais elaborado. $\mathrm{O} \S 34 \mathrm{I} \mathrm{Nr}$. $6 \mathrm{GVG}$, porém, poderia ser somente uma norma esclarecedora, declarativa e, além do mais, mostra que, para o legislador, o perigo de influência religiosa no aparelho judiciário através do Schöffe é, sim, levado a sério.

Para resolver as tensões jurídicas, é importante ter claro de qual conflito estas são oriundas: um cidadão mostra abertamente uma Weltanschauung (visão de mundo) enquanto preenche cargo público. Estamos tentados a comparar essa situação com o caso da professora de

41 Sobre o § 34 GVG ver a nota de rodapé 28. No alemão, fala-se de "Religionsdiener", terminologia antiquada para pessoas de cargo religioso: BARTHE, Christoph. Karlsruher Kommentar zur Strafprozessordnung. München: Verlag C.H. Beck, 7. Auflage 2013, § 34 GVG n 7.

42 SATZGER, Helmut. Die Schöffen im Strafprozess..., p. 525.

43 BADER, Johann. Die Kopftuch tragende Schöffin..., p. 2965.

${ }^{44}$ No Brasil, há previsão explícita referente ao júri no art. 436 § $1 \mathrm{CPP}$. 
colégio que ministra aula usando o véu muçulmano. ${ }^{45}$ Esta visão, porém, não leva em conta a situação especial do juiz leigo: ${ }^{46}$

a. o juiz não está diante de crianças que ele tem o dever de educar, possivelmente passando a influenciá-las em suas Weltanschauungen. ${ }^{47}$ Diferentemente, então, da professora de colégio que usa véu muçulmano, o dever do Estado de se manter neutro em questões de Weltanschauung e Religião (art. 140 GG em conexão com art. 137 I Weimarer Reichsverfassung) não é reforçado pelo direito e interesse dos pais de não ter os seus filhos educados conforme Weltanschauungen alheias (art. 6 I GG); ${ }^{48}$

b. o juiz leigo, ademais, não é togado, e não há lei que regule a sua aparência no tribunal. ${ }^{49}$ Ele pode se vestir como quiser, desde que não opte por uma vestimenta desrespeitosa. ${ }^{50} \mathrm{O}$ Schöffe é abertamente distinto do juiz togado, ele é abertamente "povo" e nisso encontra o seu papel por bem ou por mal..$^{51}$

45 Objeto do famoso caso do Bundesverfassungsgericht (BVerfG, "Tribunal Constitucional Federal"): BVerfGE 108, 282 (BVerfG: Urteil vom 24.09.2003 - 2 BvR 1436/02).

${ }^{46}$ Assim também: BADER, Johann. Die Kopftuch tragende Schöffin..., p. 2965.

47 BADER, Johann. Die Kopftuch tragende Schöffin..., p. 2966. Sobre isso ver também: BVerfGE 108, 282 (BVerfG: Urteil vom 24.09.2003 - 2 BvR 1436/02), item B. II. 5.

48 BADER,Johann. Die Kopftuch tragende Schöffin..., p. 2966. E também reforçado pelo direito dos filhos de não ser influenciados na sua Weltanschauung por terceiros (art. 6 I GG, alcançado certo nível de maturidade). No entanto, estamos com o BVerfG, na citada decisão BVerfGE 108, 282, ao julgar que a vedação do uso do véu e outros símbolos religiosos por professores de escolas públicas é questão para o legislador decidir, como ocorreu, em vários Länder (Estados da Federação Alemã) de forma diferente. Ver: http://www. uni-trier.de/index.php?id=24373 (acessado em 16.04.2014).

LG Bielefeld: Beschluss vom 16.03.2006 - 3221 b EH 68; LAG (Landesarbeitsgericht) Hamburg: Beschluss vom 19.03.1991 - 6 SHa 21/90, item 2.3.4.

${ }^{50}$ LAG Hamburg... (acima), item 2.3.4; PRÜTTING, Hanns. Germelmann/ Matthes/Prütting, Arbeitsgerichtsgesetz Kommentar. München: Verlag C.H. Beck, 8. Auflage 2013, § 27 n $^{\circ}$.

51 Ver discussão abaixo na parte 6.3 . 
Dito de outra forma, ao Schöffe é permitida uma aparência individualista, nos limites da decência e da dignidade da Corte, que permite também conclusões sobre as suas convicções pessoais. Pode ter roupas luxuosas ou simples, pode ser careca, ter o cabelo preso ou o cabelo solto e pode ter o cabelo coberto com o véu. Além do mais, o uso desta vestimenta é protegido pela liberdade religiosa assegurada no Art. 4 I, II GG. Portanto, enquanto não ocorrer uniformização dos Schöffen por lei, eles têm o direito de se vestir conforme as suas convicções pessoais, conquanto a dignidade da corte seja respeitada. ${ }^{52}$

No caso concreto, aliás, a decisão do Landgericht (LG, primeira ou segunda instância, ver item 3.b)) Dortmund parece ainda mais obscura: por que uma muçulmana religiosa não poderia julgar adequadamente um caso qualquer, por exemplo, de furto? Em nenhum momento o juiz alega que a Schöffin não respeita as leis alemãs, somente que ela tem uma visão que reduz o papel da mulher. Mesmo se isso fosse verdade, falta mostrar o que isso diz respeito ao caso concreto. $\mathrm{O}$ que somente reforça a posição aqui compartilhada: a inidoneidade de um Schöffe não se dá por expressões de Weltanschauung externas, mas sim por sua postura no caso concreto. Para a aparência dar motivo de suspeição, esta deve fundamentar suspeita no caso concreto. ${ }^{53}$ Além do mais, a decisão, neste caso, parece emanar de um conflito ocorrido entre o juiz e a Schöffin, que não quis tirar o seu véu, mesmo com a insistência do juiz. Para sua exclusão, ordenada pelo juiz em seguida, não se encontra base em lei incidente ${ }^{54}$ da ordem do tribunal ( $(176 \mathrm{GVG}$ ) ou, da exclusão por suspeição ( $\S 31$ I, 24 II Strafprozessordnung - StPO, "Ordem do processo penal"), pois esta não foi demonstrada. Consequentemente, a decisão é insustentável.

52 Isto excluiria, por exemplo, as burcas, que tapam todo o rosto da mulher: BADER, Johann. Die Kopftuch tragende Schöffin..., p. 2965, assim como máscaras que impedem a identificação do sujeito.

53 BADER, Johann. Die Kopftuch tragende Schöffin..., p. 2965.

54 BADER, Johann. Die Kopftuch tragende Schöffin..., p. 2966; assim também GROH, Kathrin. Angewandte Verfassungsrechtsprechung? - Die Schöffin mit Kopftuch..., p. 1026. 
Conforme a lei em vigor, a inelegibilidade ou a exclusão de um Schöffe por suspeição não podem ter base somente no fato de ele ostentar símbolos de uma Weltanschauung. ${ }^{55}$

\subsection{Críticas e avaliação}

O processo de eleição dos Schöffen é criticado principalmente por não atender, na prática, aos requerimentos do $§ 36$ II 1 GVG: falta de representatividade. ${ }^{56}$ Uns reclamam da aleatoriedade ${ }^{57}$, outros da arbitrariedade ${ }^{58}$. A importância política e social de uma participação de leigos ser representativa é evidente. Legalmente, não atender a esta previsão significa, no mínimo, uma infração do princípio do primado da lei e, no caso de uma decisão arbitrária, do princípio da igualdade assegurado no Art. 3 I do GG.

Existem sugestões para a reforma do processo de eleições. ${ }^{59}$ Não há espaço, porém, para discutir estas importantes questões neste artigo,

55 SATZGER, Helmut. Die Schöffen im Strafprozess..., p. 525. Se isto seria de fato impossível na ordem constitucional conferida pelo GG, como defendido por BADER, Johann. Die Kopftuch tragende Schöffin..., p. 2966, parece duvidoso. Ao nosso ver, uma reforma do instituto do Schöffe, que regula mais rigidamente a sua aparência na corte, poderia afetar esta discussão jurídica. A inconstitucionalidade de uma reforma hipotética neste sentido não seria “evidente", dado que o instituto do Schöffe na Alemanha não é garantia constitucional (ver nota de rodapé 146).

DUTTGE, Gunnar. Laienrichter in der Strafgerichtsbarkeit - Anspruch und Wirklichkeit..., p. 362.

57 “...man sich des Eindrucks einer gewissen Wahllosigkeit und geradezu der Unüberlegtheit nicht erwehren" könne: MACHURA, Fairneß und Legitimität, 2001, p. 299, citado por DUTTGE, Gunnar. Laienrichter in der Strafgerichtsbarkeit-Anspruch und Wirklichkeit..., p. 362.

58 VULTEJUS, Ulrich/VOLK, Klaus. Pro \& Contra: Stärkung der Rolle der Schöffen. Zeitschrift für Rechtspolitik, Heft 02/2004, p. 63: "Arbeiter nur selten vorgeschlagen".

59 VULTEJUS, Ulrich/VOLK, Klaus. Pro \& Contra: Stärkung der Rolle der Schöffen..., p. 63: importante que haja mais miscigenação entre as classes, o que não ocorre no presente (faltam a classe baixa e a classe alta). Na citada fonte, VOLK expõe que sempre falamos do Schöffe somente como cidadão 
que visa apresentar a situação de lege lata na Alemanha e enfrentar a crítica à participação do leigo no processo penal em si. Tendo sido apresentado quem é o Schöffe e como ele chega ao cargo, passamos a externar de que forma se dá a sua efetiva participação no sistema penal alemão.

\section{A COMPETÊNCIA do SCHÖFFE NO SISTEMA PENAL ALEMÃo}

O Schöffe não constitui um pilar próprio na arquitetura processual alemã, no sentido de usufruir de poderes próprios e únicos e encontrar nestes o seu papel sistêmico. Portanto, não é um "Jury" que, tradicionalmente, tem o poder, único e próprio, de julgar os fatos e/ou a culpa, sem decidir sobre a qualidade e a quantidade da pena. ${ }^{60}$ Este "jury" foi abandonado na Alemanha em $1924,{ }^{61}$ pouco depois da introdução deste mesmo sistema no Brasil (1922). ${ }^{62}$ O Schöffe, em contrapartida, é concebido e inserido no processo penal como juiz, portanto, a princípio, com os mesmos direitos do juiz técnico, "togado", e fazendo parte do mesmo pilar processual.

Salvo exceções previstas pela lei, o Schöffe exerce no "processo principal" o pleno cargo de juiz, com o mesmo peso de voto dos juízes do Amtsgericht e participa também das decisões em curso do processo principal, que não tem relação alguma com a sentença e as quais também podem ser tomadas sem oralidade ( $\$ 30$ I do Gerichtsverfassungsgesetz- GVG).

disposto a julgar outros, mas nunca do fato de que ele pode ser, e às vezes é, forçado a assumir esta função. Em 2004, houve uma reforma na Alemanha que é julgada "irrelevante" por DUTTGE, Gunnar. Laienrichter in der Strafgerichtsbarkeit-Anspruch und Wirklichkeit..., p. 359.

${ }^{60}$ VOLK, Klaus. GRUNDKURS StPO..., p. 14.

${ }_{61}$ O Jury era chamado na Alemanha de "Geschworene". Outra grande reforma ocorreu em 1975: anteriormente havia o Schöffengericht com três juízes técnicos e seis Schöffen. Ver: DUTTGE, Gunnar. Laienrichter in der Strafgerichtsbarkeit - Anspruch und Wirklichkeit..., p. 358; SATZGER, Helmut. Die Schöffen im Strafprozess..., p. 519.

${ }^{62}$ PACELLI DE OLIVEIRA, Eugênio. Curso de processo penal. Rio de Janeiro: Lúmen Júris, $10^{\circ}$ edição, 2008, p. 563. 
Nos termos do $\S \S 11$ I Nr. 2a), 11 I Nr. 3 Strafgesetzbuch (StGB, "Código penal alemão") o Schöffe é considerado funcionário público, punível por crimes específicos cujo tipo exige este elemento típico do autor. ${ }^{63}$ Também é comprometido ao sigilo, quando exigido, ${ }^{64} \mathrm{e}$ em caso de infração é punível nos termos do $§ 353 \mathrm{~b}$ StGB. Como juiz, o Schöffe é independente (Art. 92, 97 I GG). Entretanto, como ele não é funcionário público no sentido trabalhista (Beamter), a independência e a segurança pessoal (para os juízes togados, art. 97 II GG e Art. $33 \mathrm{~V}$ GG) não estão garantidas através de norma constitucional, ${ }^{65}$ mas do $\S$ 44 II DRiG: assim como no Brasil (ver art. $444 \mathrm{CPP}$ ), uma dispensa antecipada demanda decisão judicial. A suspeição do Schöffe é tratada da mesma forma que a suspeição do juiz togado, por exceção de suspeição (§ 31 I StPO e $§ 24$ II StPO). ${ }^{66}$

A competência do júri brasileiro dá-se constitucionalmente e trata-se dos crimes dolosos contra a vida (art. 5 XXXVIII CF). ${ }^{67}$ Os Schöffen, por outro lado, não são previstos explicitamente na constituição alemã ${ }^{68}$ e atuam nos Tribunais do Amtsgericht e no Landgericht. Trata-se da primeira instância em crimes "leves" (Amtsgericht) e "graves" (Landgericht):

a. O Amtsgericht julga tudo aquilo que não é competência do Landgericht ou do Oberlandesgericht ("Supremo Tribunal Estadual”), até uma pena máxima de quatro anos (§ $24 \mathrm{I} \mathrm{Nr.}$

${ }^{63}$ Regulamento semelhante ao brasileiro, onde o membro do júri é criminalmente equiparado ao juiz togado (art. $445 \mathrm{CPP}$ ).

${ }^{64}$ Em principio somente em julgamentos a porta fechada (§ $\left.174 \mathrm{GVG}\right)$. A parte majoritária da doutrina, porém, defende também o sigilo referente à deliberação de sentença ( $§ 43$ em conjunto com $\S 45 \mathrm{~S}$. 2 DRiG), como abrangido pela punibilidade nos termos do $\$ 353 \mathrm{~b}$ StGB. Ver: SATZGER, Helmut. Die Schöffen im Strafprozess..., p. 526.

65 SATZGER, Helmut. Die Schöffen im Strafprozess..., p. 523.

${ }^{66}$ Outra coisa em comum com o sistema brasileiro, ver: PACELLI DE OLIVEIRA, Eugênio. Curso de processo penal..., p. 580. Aqui, adicionalmente exceção por art. 448 e 449 CPP.

${ }^{67}$ PACELLI DE OLIVEIRA, Eugênio. Curso de processo penal..., p. 570.

${ }^{68}$ Ver nota de rodapé 146. 
1 e Nr. 2 GVG) ${ }^{69}$ Há dois tipos de câmaras no Amtsgericht: o Strafrichter e o Schöffengericht. O Strafrichter é composto por somente um juiz togado e julga casos em que a expectativa de pena máxima de detenção ou prisão é de dois anos ${ }^{70}$ ou ações penais de iniciativa privada ( $\$ 25 \mathrm{GVG}$ ). O lugar do Schöffe é no Schöffengericht, onde as decisões são tomadas por um juiz técnico e dois juízes leigos ( $\S 28 \mathrm{~s}$. GVG). Trata-se de casos em que a expectativa de pena é de dois a quatro anos de prisão;

b. O Landgericht julga casos de crimes cuja tipicidade depende do resultado morte, $\S 74 \mathrm{II} \mathrm{GVG,71}$ ou casos em que a expectativa de pena é de mais de quatro anos de prisão (\$74 I 2 GVG). Estes crimes são julgados pela große Strafkammer, composta por três juízes técnicos e dois leigos ( $\$ 76$ I 11 . Var. GVG). ${ }^{72}$ Quando houver uma "Berufung" - a apelação, com efeito de reabertura da apreciação de prova ("fato") contra uma decisão do Amtsgericht, o Landgericht vira segunda instância, na assim chamada "kleine Strafkammer", composta por um juiz técnico e dois juízes leigos (\$ 76 I 12. Var. GVG). Neste caso, o Schöffe também julga apelações. ${ }^{73}$

${ }^{69}$ A pena máxima aplicável pelo Amtsgericht é de quatro anos de prisão ( $\$ 24$ II GVG). Há ainda outras exceções para competência do Amtsgericht, ver $\S$ 24 I Nr. 2 2. Var. e Nr. 3 GVG.

70 "Expectativa de pena" se refere à pena que, considerando o caso concreto, pode ser esperada, e não a pena máxima que o tipo penal permite. $O$ furto $(\S$ 242 I StGB), por exemplo, tem uma pena máxima de cinco anos de prisão. Porém, em regra, um furto de algo de valor não muito grande, e por alguém sem reincidência não vai levar a uma pena maior que dois (2) anos de prisão, e seria, em consequência, julgado pelo Strafrichter (\$25 GVG).

71 Assim podemos, grosso modo, resumir os 29 tipos penais que fazem parte do catálogo do § 74 II GVG.

72 Essa große Strafkammer pode decidir atuar com somente dois juízes leigos e dois togados (§ 76 II GVG), o que ocorre com frequência, DUTTGE, Gunnar. Laienrichter in der Strafgerichtsbarkeit-Anspruch und Wirklichkeit..., p. 359, nota de rodapé 12 .

73 Entretanto, somente "Berufungen", apelações com efeito de nova apreciação dos fatos, aceitação de prova etc. Nunca a Revision (somente decisão sobre a lei, não o fato), uma decisão legislativa que é defendida por SATZGER, Helmut. Die Schöffen im Strafprozess..., p. 523. 
c. Contudo, o Schöffe não julga em todos os casos de primeira instância ${ }^{74}$ : não participa do Oberlandesgericht (OLG, "Supremo Tribunal Estadual"), que é a primeira instância em crimes como genocídio, ataques contra representantes estrangeiros e outros que, grosso modo, concernem a segurança pública e relações internacionais $(§ 120 \mathrm{GVG}),{ }^{75}$ além de ser última instância em casos de competência do Amtsgericht. A última instância, em casos que se iniciam no Landgericht ou no Oberlandesgericht, é o Bundesgerichtshof (BGH), que é

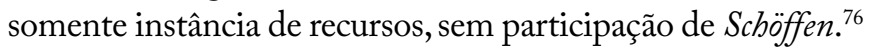

Assim, dos casos criminais julgados por tribunal, somente $30 \%$ tem participação do Schöffe. ${ }^{77}$ Trata-se de criminalidade leve a grave, excluindo a criminalidade "levíssima" (Strafrichter) e "gravíssima" (OLG). Em 2001, havia na Alemanha ${ }^{78} 36$ mil Schöffen principais, ou seja, não Hilfsschöffen. ${ }^{79}$ Visto quem é o Schöffe e como ele se insere no sistema penal do direito alemão, veremos, então, qual é o seu papel no processo penal, sobretudo em relação aos juízes togados.

\section{O PAPEL do SCHÖFFE NO PROCESSO PENAL ALEMÃo}

Sobre o papel do Schöffe, a primeira afirmação do § 30 I GVG é de que, salvo exceções previstas pela lei, o Schöffe exerce no "processo

${ }^{74}$ Como já vimos na parte 3.a), no Amtsgericht como primeira instância, casos do Strafrichter são julgados sem participação do Schöffe.

75 Isto levou VOLK, Klaus, a dizer: "Also misstraut man dem Laien eben doch" (Desconfia-se do leigo sim), citado por DUTTGE, Gunnar. Laienrichter in der Strafgerichtsbarkeit-Anspruch und Wirklichkeit..., p. 359, nota de rodapé 16.

76 Como efeito, as instâncias penais na Alemanha se dão das seguintes três formas, dependendo da competência de primeira instancia: AG - LG - OLG; LG - BGH; OLG - BGH ( $\S 23$ ss. GVG).

77 SATZGER, Helmut. Die Schöffen im Strafprozess..., p. 520 (2010); outra fonte fala de somente 2\%: SPONA, Laienbeteiligung im Strafverfahren, 2000, p. 74 e 129, citado por: DUTTGE, Gunnar. Laienrichter in der Strafgerichtsbarkeit-Anspruch und Wirklichkeit..., p. 360, nota de rodapé 44.

78 DUTTGE, Gunnar. Laienrichter in der Strafgerichtsbarkeit - Anspruch und Wirklichkeit..., p. 362.

79 § 42 I Nr. 2 GVG, ver nota de rodapé 16. 
principal" o pleno cargo de juiz, com o mesmo peso de voto dos juízes do Amtsgericht. Portanto: (1.) dispõe do mesmo peso de voto, mas exerce o cargo somente (2.) no "processo principal" (previsão reforçada em $\S 30$ II, 76 I 2 GVG e 33a II JGG) e (3.) "salvo exceções previstas pela lei”.

\subsection{Peso de Voto}

No Brasil, o Conselho de Sentença é composto por sete jurados (art. $447 \mathrm{CPP}$ ) que julgam em segredo e por maioria de votos sobre a condenação ou a absolvição do acusado (art. 487 ss. CPP), julgando (somente) com a própria íntima convicção. ${ }^{80}$ Como os Schöffen, por outro lado, são concebidos como juízes, o seu julgamento é guiado pelo princípio do livre convencimento ( $\$ 261$ StPO), diferença substancial do jurado brasileiro. Com o mesmo peso de voto, os Schöffen dispõem do poder de, em conjunto, proferir decisões contra os juízes togados. No Schöffengericht do Amtsgericht, isto se dá por representarem a maioria de dois (2) dos três (3) juízes. ${ }^{81}$ No Landgericht, eles constituem somente a metade (2/4) ou somente dois quintos (2/5) do conselho de sentença. ${ }^{82} \mathrm{O} \S 263 \mathrm{StPO}$ prevê, porém, uma maioria de votos de dois terços (2/3) para todas as decisões contra reo referentes a culpa e pena. ${ }^{83}$ Os juízes leigos podem, então, em conjunto, bloquear qualquer condenação ou pena alta no Landgericht, e no Amtsgericht até mesmo condenar contra o voto do juiz togado. Mas, na prática, este poder é desperdiçado: decisões tomadas pelo voto dos Schöffen contra os juízes

80 Sobre isto ver: PACELLI DE OLIVEIRA, Eugênio. Curso de processo penal..., p. 566; VASCONCELLOS, Vinicius Gomes de; GALÍCIA, Caíque Ribeiro. Tribunal do júri na justiça criminal brasileira: críticas e propostas de reforma para a restituição de sua função de garantia no processo penal democrático. Revista Eletrônica de Direito Processual, 2014, volume 13, p. 903.

81 Sobre o Schöffengericht ver acima parte 3.a).

${ }_{82}$ Sobre o Landgericht ver acima parte 3.b).

83 Contraria a regra geral do $\S 196$ I GVG. Ver: DUTTGE, Gunnar. Laienrichter in der Strafgerichtsbarkeit - Anspruch und Wirklichkeit..., p. 360. 
togados só ocorrem em 1,4\% dos casos. ${ }^{84}$ Ademais, há relatos de que os bloqueios podem ser "superados" pelo juiz togado, se ele provocar o recurso contra a decisão através de uma fundamentação defeituosa, já que a sentença não é assinada pelos Schöffen ${ }^{85}$ ( $\$ 275$ II 3 StPO) (ver parte 4.3.b)). Consequentemente, o proferimento de uma sentença eficaz pelos Schöffen contra o voto dos juízes togados é situação teoricamente possível, mas praticamente muito rara.

\subsection{Processo Principal}

O processo penal alemão é divido em três etapas: ${ }^{86} \mathrm{o}$ Ermittlungsverfahren (inquérito ou fase preliminar) ${ }^{87}, \mathrm{o}$ Zwischenverfahren (processo intermediário, onde são julgadas a acusação e a abertura do processo principal, semelhante à instrução preliminar seguida da pronúncia) e o Hauptverfahren (processo principal, semelhante à chamada fase julgamento). A participação do Schöffe é restrita ao processo principal (§ 30 I GVG), após a aceitação da acusação pelo juiz. Portanto, ele não participa de decisões tomadas antes e depois do processo principal. Neste âmbito a questão das decisões (a) tomadas durante a suspensão, especialmente sobre a prisão preventiva, assim como (b) as questões e interrogações de testemunhas pelo $S c h \ddot{f f f e ~ e ~(c) ~ a ~ c o n f e r i c ̧ a ̃ o ~ d o s ~ a u t o s ~ d o ~}$ processo merecem destaque.

${ }^{84}$ CASPER/Zeisel, in: dies. (Hrsg.), Der Laienrichter im Strafprozess, 1979, S. 26, 84 f.: "Änderung des Schuldspruchs durch Schöffen nur in 1,4\% der Fälle", citado por: DUTTGE, Gunnar. Laienrichter in der Strafgerichtsbarkeit - Anspruch und Wirklichkeit..., p. 360, nota de rodapé 40.

DUTTGE, Gunnar. Laienrichter in der Strafgerichtsbarkeit - Anspruch und Wirklichkeit..., p. 360, citando: WETTE, zit. nach MACHURA, Fairneß und Legitimität, 2001, p. 245: "Richter rühmen sich manchmal damit, dass sie ihr schriftliches Urteil nach einer Abstimmungsniederlage so formulieren, dass es aufgehoben werden muss". Sobre este ponto, ver ainda notas de rodapé 137 e 168. VOLK, Klaus. GRUNDKURS StPO..., p. 7 s.

87 Sobre a fase preliminar no Brasil ver: GIACOMOLLI, Nereu José. A fase preliminar do processo penal. Rio de Janeiro: Lumen Juris, 2011. 
a) Decisão sobre a prisão preventiva: a extensão da exclusão de decisões tomadas durante suspensões do processo principal ( $\$ 30 \mathrm{II}$ GVG) não é pacífica na doutrina alemã. A questão surgiu acerca da decisão sobre a prisão preventiva, quando competência do tribunal principal ( $§ 125$ II, 126 II StPO) e quando tomada durante uma suspensão do processo ( $\$ 229 \mathrm{StPO}) .^{88}$ Aqui, há três posicionamentos: ${ }^{89}$ o primeiro é que, partindo do princípio de que o $S c h o ̈ f f e$ é basicamente equiparado ao juiz togado, a decisão tomada durante o processo principal deve, de todo modo, ser tomada com a sua participação. ${ }^{90} \mathrm{~A}$ posição menos principiológica defende que, considerando o $§ 30$ I e II GVG i.a., uma participação é indicada somente quando não houver suspensão do processo principal. Em caso de suspensão, não deverá haver participação. ${ }^{91} \mathrm{O}$ BGH${ }^{92}$, entretanto, defendeu outra posição, como já havia sido feito por parte da jurisprudência e da doutrina. ${ }^{93}$ Segundo este raciocínio, não há necessidade de participação do Schöffe na decisão sobre a prisão preventiva, nem quando tomada durante o processo principal ininterrupto. Esta solução poderia ser considerada contra legem, já que o juiz leigo seria excluído de uma decisão judicial após a abertura e durante o processo principal. Entretanto, além de uma possível interpretação gramatical do § 30 I e II do GVG no sentido de que o "processo principal" não inclui a decisão acerca da prisão preventiva, ${ }^{94}$ podemos também considerar uma interpretação constitucional partindo do princípio do juiz natural. Interpretando o $§ 30 \mathrm{GVG}$

88 BARTHE, Christoph. Karlsruber Kommentar zur Strafprozessordnung..., § $30 \mathrm{GVG} \mathrm{n}^{\circ} 5 \mathrm{~s}$.

${ }^{89}$ MOSBACHER, Andreas. Aktuelles Strafprozessrecht. Juristische Schulung, 8/2011, p. 708, p. 713.

OLG Koblenz, Beschluss vom 17.03.2009 - 1 Ws 120/09.

OLG Naumburg, Beschluss vom 21.06.2001 - 1 Ws 239/01. Beschluss vom 22.04.1998 - 3 Ws 182/98; SATZGER, Helmut. Die Schöffen im Strafprozess..., p. 524, com mais fontes.

94 Porém, interpretação inidônea visto que decisões sem oralidade e sem nexo com a sentença durante o processo principal também devem ser tomadas com a participação do Schöffe (§30 I GVG, ver parte 3). 
a favor da participação do Schöffe na decisão sobre a prisão preventiva durante o processo principal, tal participação dependeria do momento em que a promotoria requereria a prisão preventiva. Antes da abertura do processo principal (sem Schöffe) ou depois (com Schöffe). Assim, a competência do juiz leigo, e com ela a constituição do tribunal para esta decisão, dependeriam da vontade da promotoria. ${ }^{95}$ Contra isto foi sustentado o argumento de que o princípio do juiz natural também seria atendido se houvesse sempre a participação do Schöffe, já que neste caso não haveria risco de manipulação. ${ }^{96}$ Entretanto, vigem no processo alemão os princípios da aceleração e do prazo adequado do processo (Beschleunigungsgebot): ${ }^{97}$ o chamamento dos Schöffen para o julgamento da prisão preventiva, por definição urgente, pode significar um prolongamento indevido. ${ }^{98}$ Portanto, parte da doutrina segue o $\mathrm{BGH}$ na sua decisão de permitir a exclusão do Schöffe de todas as decisões sobre a prisão preventiva, ${ }^{99}$ e aplica esta interpretação constitucional ${ }^{100}$ do $§ 30 \mathrm{GVG}$, excluindo a participação do Schöffe em todas as decisões sem nexo com a sentença, ${ }^{101}$ todavia este último ponto continua discutido. ${ }^{102}$ Em vista da lei, parece-nos que uma participação do Schöffe dificilmente pode ser negada a todas as decisões durante o processo principal mas sem nexo com a sentença, pois infringe claramente o

95 SATZGER, Helmut. Die Schöffen im Strafprozess..., p. 524, com mais fontes.

96 DEHN,Bertram.BesetzungbeiEntscheidungaußerhalbder Hauptverhandlung. Neue Zeitschrift für Strafrecht, 1997, p. 606, p. 607 s.

97 SATZGER, Helmut. Die Schöffen im Strafprozess..., p. 524; VOLK, Klaus. GRUNDKURS StPO..., p. 172 (§ $\left.18 \mathrm{n}^{\circ} 11\right)$.

98 SATZGER, Helmut. Die Schöffen im Strafprozess..., p. 524.

99 Salve a decisão de continuação da prisão preventiva proferida com a sentença: SATZGER, Helmut. Die Schöffen im Strafprozess..., p. 524; MOSBACHER, Andreas. Aktuelles Strafprozessrecht..., p. 713.

${ }^{100}$ Atendendo aos princípios de prazo adequado do processo e do juiz natural, SATZGER, Helmut. Die Schöffen im Strafprozess..., p. 524.

${ }^{101}$ BARTHE, Christoph. Karlsruher Kommentar zur Strafprozessordnung..., § $30 \mathrm{GVG} \mathrm{n}^{\circ} 5 \mathrm{c}$.

${ }^{102}$ Outra vez lembramos o texto da lei do $§ 30$ I GVG: decisões sem oralidade e sem nexo com a sentença durante o processo principal também devem ser tomadas com a participação do Schöffe (ver parte 3 deste artigo). Ver também SATZGER, Helmut. Die Schöffen im Strafprozess..., p. 523. 
§ 30 I GVG. Além do mais, o princípio de prazo adequado aqui não se aplica com tanto rigor, já que o processo pode demorar mais, não só para a anulação da prisão preventiva, mas também para a decisão sobre o ordenamento da mesma, momento em que o prazo adequado seria contra reo. Contudo, a solução do BGH é preferível frente à solução que considera somente o momento da decisão sobre a prisão preventiva, antes ou depois do processo principal. Neste caso, o princípio do juiz natural encontrar-se-ia tangido.

b) Questões e interrogações de testemunhas: no processo principal, como já referido, o Schöffe tem, a princípio, o papel do juiz togado (§30 GVG). Pode fazer perguntas, deferir pedidos e interrogar testemunhas ( $\$ 240$ II 1 StPO). Aqui, há semelhança ao júri brasileiro, que também tem o direito de fazer perguntas. ${ }^{103}$ Segundo Rennig ${ }^{104}$, porém, 57\% dos Schöffen não fizeram uma só pergunta durante o processo principal, quase $12 \%$ fizeram somente questões sobre temas já tratados e quase $24 \%$ sobre aspectos que em perspectiva jurídica pareciam irrelevantes. Mesmo durante a deliberação da sentença, em 50\% dos casos os Schöffen mal se manifestaram, em 30\% se manifestaram após serem perguntados e cerca de $20 \%$ dos casos os Schöffen se manifestaram por iniciativa própria.

c) Conferição dos autos: inicialmente, a posição do Schöffe no processo principal, e não no processo intermediário onde a abertura do processo principal é julgada, ${ }^{105}$ assegura a sua função como representante do povo, tomando a decisão - ao julgar pelo princípio do livre convencimento (ver acima item 4.1) - somente a partir do caso exposto no processo principal (Inbegriff der Verhandlung). O Schöffe é um juiz que é confrontado com provas que atendem rigidamente aos princí-

\section{${ }^{103}$ Art. 473 § 2 CPP.}

${ }^{104}$ RENNIG, Die Entscheidungsfindung durch Schöffen und Berufsrichter in rechtlicher und psychologischer Sicht. Empirische, rechtsdogmatische und psychologisch-theoretische Untersuchungen zur Laienbeteiligung an der Strafgerichtsbarkeit, 1993, S. 530 s., citado por: DUTTGE, Gunnar. Laienrichter in der Strafgerichtsbarkeit - Anspruch und Wirklichkeit..., p. 361. $105 \S 199$ StPO, ver VOLK, Klaus. GRUNDKURS StPO..., p. 8. Sobre a exclusão do Schöffe desta decisão: DUTTGE, Gunnar. Laienrichter in der Strafgerichtsbarkeit - Anspruch und Wirklichkeit..., p. 360. 
pios da imediatidade e da oralidade ${ }^{106}$ (ver o referido no $\S 249,261$ $\mathrm{StPO}$ ). Assim, por muito tempo, não havia permissão para o Schöffe conferir os autos do processo. ${ }^{107} \mathrm{Da}$ mesma forma, os autos do inquérito estariam vedados, para que o Schöffe não fosse contaminado pelo texto tendencioso da acusação ${ }^{108}$ (ver Segmento 126 III 1 Richtlinien für das Strafverfahren und das Bußgeldverfahren - RiStBV, "Diretrizes para o processo penal e o processo das contravenções", que é somente uma diretriz, não lei). Aqui, há, então, outra diferença fundamental do jurado brasileiro, que tem acesso aos autos, mas é mantido em isolamento de notícias de opinião durante a deliberação, ${ }^{109}$ algo que não ocorre na Alemanha, onde o processo de deliberação de julgamento com o Schöffe é um processo de comunicação entre os julgadores. ${ }^{110}$ Recentemente, o $\mathrm{BGH}$ se posicionou de outra forma referente aos autos do processo: ${ }^{111}$ em casos demorados e/ou de alta complexidade (crimes econômicos complexos, verbi gratia), a função do Schöffe de julgar o caso não pode ser atendida sem que este revise os autos do processo. ${ }^{112} \mathrm{O}$ juiz, Schöffe ou togado, deve decidir levando em consideração todos os fatos do caso, e então deve ter a opção de se informar através dos autos quando a complexidade do caso não permite a decisão partindo somente do exposto no processo principal confuso e longo ${ }^{113}$ Este raciocínio, de permitir exceção em casos complexos, também foi adotado para os autos do in-

${ }^{106}$ BÖRNER, René. Die Beteiligung von Laienrichtern am Strafprozess als Erkenntnismittel einer funktionellen Theorie des Strafprozessrechts. Strafverteidiger Forum, 11/2012, p. 434, p. 439; SATZGER, Helmut. Die Schöffen im Strafprozess..., p. 523; entre outros.

${ }^{107}$ SATZGER, Helmut. Die Schöffen im Strafprozess..., p. 523.

${ }^{108}$ SATZGER, Helmut. Die Schöffen im Strafprozess..., p. 524.

${ }^{109}$ Art. 473 § 3, art. 479 CPP. Ver: PACELLI DE OLIVEIRA, Eugênio. Curso de processo penal..., p. 587.

${ }^{110}$ Ver: BÖRNER, René. Die Beteiligung von Laienrichtern am Strafprozess..., p. 437.

${ }^{111}$ BGH: Urteil vom 26.03.1997 - 3 StR 421/96. Diferentemente de antes: BGH, Urteil vom 5.1.1954 - 1 StR 476/53.

${ }_{112}$ BGH: Urteil vom 26.03.1997 - 3 StR 421/96; SATZGER, Helmut. Die Schöffen im Strafprozess..., p. 524.

${ }^{113}$ SATZGER, Helmut. Die Schöffen im Strafprozess..., p. 523 s. 
quérito. ${ }^{114}$ Börner ${ }^{115}$, salienta que, para cumprir com a função do Schöffe como juiz garantidor da oralidade e da imediatidade, os autos deverão ser revelados não quando estes forem apenas convenientes, mas necessários para o seu julgamento informado.

\subsection{EXCEÇÕES PREVISTAS PELA LEI}

A lei prevê várias regras excluindo o Schöffe de decisões tomadas durante o processo principal. Mesmo equiparado, a princípio, ao Schöffe, o juiz togado é o condutor principal do processo na função do juiz presidente ("Vorsitzender"): "a condução do julgamento, a interrogação do acusado e a aceitação de provas é feita pelo presidente da câmara” ( 238 I StPO). ${ }^{116} \mathrm{O}$ Schöffe não decide sobre a exclusão por suspeição ( $\$ 31$ II S. 1 StPO), e a interrogação de testemunhas com menos de 18 anos de idade é feita somente pelo presidente da câmara (\$ 241a I StPO). Aqui também há discussões a destacar: (a) a participação no debate da situação processual e (b) a isenção do dever de assinar a fundamentação da sentença são controvertidas.

a) Debate da situação processual: o Schöffe, como juiz natural do caso, não está excluído da Verständigung ("barganha”) (§ 257c StPO em conexão com $\S 30$ I GVG). ${ }^{117}$ A situação complica em relação ao "debate da situação processual", concebido em parte como preparatório para a "barganha", ${ }^{118}$ e iniciado pela promotoria ( $§ 160 \mathrm{~b}$ StPO), ou pelo

${ }^{114}$ Seg. 126 III frase 2 RiStBV, porém como diretriz sem força de lei.

115 BÖRNER, René. Die Beteiligung von Laienrichtern am Strafprozess..., p. 439. Assim concordamos, ver item 5 e nota de rodapé 175.

116 "Die Leitung der Verhandlung, die Vernehmung des Angeklagten und die Aufnahme des Beweises erfolgt durch den Vorsitzenden".

${ }^{117}$ Sobre os problemas da "barganha" na Alemanha ver: SCHÜNEMANN, Bernd. Ein deutsches Requiem auf den Strafprozess des liberalen Rechtsstaats. Zeitschrift für Rechtspolitik, 2009, p. 104.

${ }^{118}$ JAHN, Matthias/MÜLLER, Martin. Das Gesetz zur Regelung der Verständigung im Strafverfahren - Legitimation und Reglementierung der Absprachenpraxis. Neue juristische Wochenschrift, 2009, p. 2625, p. 2627; SATZGER, Helmut. Die Schöffen im Strafprozess..., p. 525. 
tribunal ( $\$ 202 \mathrm{a}$ StPO). Como estas normas se aplicam ao processo intermediário, anterior ao processo principal, o Schöffe não participa. Porém, o § 212 StPO prevê a aplicação do § 202a StPO após a abertura do processo principal e, assim, a questão se coloca. ${ }^{119}$ Referente ao "debate da situação processual”, temos que levar em consideração que este permite o encaminhamento da "barganha", mas não a "barganha" em si, que só pode ser decidida com a participação do Schöffe (§ 257c StPO em conexão com § 30 I GVG). Além do mais, para a validação do encaminhamento da barganha no "debate da situação processual”, este deve ser mencionado pelo presidente da câmara no processo principal (§ $243 \mathrm{IV}$ $\mathrm{StPO}$ ), e devidamente protocolado (§ $273 \mathrm{Ia} \mathrm{StPO}) .{ }^{120}$

Há quem defenda que o Schöffe não deveria ser incluído no "debate da situação processual". ${ }^{121}$ Outros, porém, observam que com a participação do Schöffe frente a uma "barganha" que já está encaminhada a partir do "debate da situação do processo" pela promotoria, defesa e presidente da câmara, o Schöffe dificilmente ousará se opor e que, portanto, sua participação somente no momento da decisão sobre a "barganha”, mesmo que anteriormente informado sobre o encaminhamento, se insere muito tarde; por isso, defendem sua participação já no debate da situação processual. ${ }^{122}$

A "barganha” do $§ 257$ c StPO é um instituto muito discutido e de duvidosa legitimidade frente a vários princípios fundamentais do processo penal e da constituição. ${ }^{123}$ Não cabe aqui se posicionar acerca dele em si mas somente a respeito da participação do Schöffe nele. Como a "barganha" é um instrumento para concluir o processo principal, a participação do Schöffe, já que é juiz natural, é indispen-

${ }^{119}$ SATZGER, Helmut. Die Schöffen im Strafprozess..., p. 525.

${ }^{120}$ SATZGER, Helmut. Die Schöffen im Strafprozess..., p. 525.

${ }^{121}$ JAHN, Matthias/MÜLLER, Martin. Das Gesetz zur Regelung der Verständigung im Strafuerfahren..., p. 2627.

${ }^{122}$ FISCHER, Strafverteidiger Forum, 2009, p. 177, p. 183, citado por: SATZGER, Helmut. Die Schöffen im Strafprozess..., p. 525.

${ }^{123}$ SCHÜNEMANN, Bernd. Ein deutsches Requiem auf den Strafprozess des liberalen Rechtsstaats..., p. 104. Sobre a discussão principiológica e a situação antes da reforma de 2009 ver também VOLK, Klaus. GRUNDKURS StPO..., p. 277 (§ 30). 
sável. A participação na preparação da mesma, no "debate da situação processual”, por outro lado, é um instituto que é concebido como um processo preparatório para a "barganha", semelhante ao processo intermediário em relação ao processo principal. E é justamente neste processo intermediário que o "debate da situação processual" normalmente ocorre ( $§ 160 \mathrm{~b}$ StPO). Como não há participação do Schöffe no processo intermediário, é coerente prever que a mesma tampouco ocorrerá no debate, mesmo que este ocorra por acaso durante o processo principal.

Também o argumento de que o Schöffe, excluído do debate da situação processual, dificilmente irá se opor à barganha, não convence. ${ }^{124} \mathrm{~A}$ situação é semelhante ao julgamento do processo principal, onde ele também se vê diante de um processo de julgamento já encaminhado, ${ }^{125}$ situação que não se corrige pela participação do Schöffe no "debate da situação processual". Adicionalmente, como argumentado em referência à decisão sobre a prisão preventiva, ${ }^{126}$ a participação do Schöffe traz consigo um custo para os princípios do prazo adequado e da aceleração do processo, que são os principais motivos de ser do instituto da barganha. ${ }^{127}$ Assim, manter o instituto da barganha, mas exigir uma participação do Schöffe já no debate da situação processual contrapõe-se aos argumentos que sustentam justamente a existência da barganha. Todo o exposto, porém, não substituiria a lei, e o $§ 30$ I GVG prevê expressamente a participação do Schöffe em decisões tomadas durante o processo principal. No entanto, a participação no

${ }^{124}$ Posição fortalecida pelos argumentos expostos acima, de que os seus direitos já estão garantidos através da inclusão mandatória do "debate da situação processual” no protocolo ( $\$ 273 \mathrm{Ia}$ StPO) (ver nota de rodapé 120 ).

${ }^{125}$ Isto nos faz pensar na "dissonância cognitiva" dos juízes no processo penal alemão, ver: SCHÜNEMANN, Bernd. Der Richter im Strafverfabren als manipulierter Dritter? Zur empirischen Bestätigung von Perseveranz- und Schulterschlussefekt. Strafverteidiger (Zeitschrift), 2000, p. 159. Sobre a "estranha” ausência do Schöffe no processo intermediário: DUTTGE, Gunnar. Laienrichter in der Strafgerichtsbarkeit-Anspruch und Wirklichkeit..., p. 360.

126 Ver parte 4.2 a).

127 Sobre as origens da Barganha VOLK, Klaus. GRUNDKURS StPO..., p. $277(\S 30)$. 
debate da situação processual não é decisão judicial. Considerando então que não há previsão expressa da participação do Schöffe no debate da situação processual e considerando também os argumentos acima expostos, uma participação do Schöffe no "debate da situação processual", de lege lata não nos parece mandatória, nem quando ocorrer durante o processo principal. ${ }^{128}$

b) Dever de assinar sentença: uma exceção que ocorre também no Brasil ${ }^{129}$ é o $§ 275$ II 3 StPO: não é necessário assinar a fundamentação, apesar de a responsabilidade e o peso de voto serem equiparados aos do juiz togado. O fato de o Schöffe não assinar a sentença $a^{130}$ permite maior velocidade na expedição da mesma, já que sua formulação pode ser feita com calma ${ }^{131}$ pelo juiz togado ou pelos juízes togados sozinho(s), sem necessidade de chamar os Schöffen para um ato meramente formal. Porém, vozes na doutrina brasileira ${ }^{132}$ e alguns autores na Alemanha também ${ }^{133}$ consideram o simbolismo e o efeito psicológico do ato de assinar muito significante.

De fato, o assinar é um ato de sanção e valorização da sentença escrita que conclui exclusivamente o processo e que, portanto está regulamentada pelo $§ 275 \mathrm{StPO}$, sem a jurisdição permitir muito descuido. ${ }^{134}$ O dever de justificar uma decisão, relacionado à assinatura da mesma, é

${ }^{128}$ Isto mantém coerência com o defendido referente à decisão do BGH sobre a prisão preventiva, parte 4.2 a) do presente artigo.

${ }^{129}$ No sentido de ausência de fundamentação por parte do jurado. Ver: PACELLI DE OLIVEIRA, Eugênio. Curso de processo penal..., p. 565.

${ }^{130} \mathrm{E}$ se for assinar, não tem problema: BGH: Entscheidung vom 06.08 .1993 StbSt (R) 1/93.

${ }^{131} \mathrm{O}$ prazo, a principio, é de cinco semanas, dependendo da quantidade das sessões no processo principal, ver $§ 275$ I 2 StPO.

${ }^{132}$ PACELLI DE OLIVEIRA, Eugênio. Curso de processo penal..., p. 565.

${ }^{133}$ DUTTGE, Gunnar. Laienrichter in der Strafgerichtsbarkeit - Anspruch und Wirklichkeit..., p. 360, citando mais outros.

${ }^{134}$ Por exemplo, não é permitida a assinatura prévia de uma sentença posteriormente alterada, pois a assinatura sempre deve referir-se ao texto, correspondendo ao resultado da deliberação do julgamento, e conhecido pelo assinante em todos os detalhes, BGH: Beschluß vom 10.01.1978 - 2 StR 654/77. Sobre o § 275 ver: GREGER, Anette. Karlsruher Kommentar zur Strafprozessordnung. München: Verlag C.H. Beck, 7. Auflage 2013, § 275 n² 21-37. 
amplamente reconhecido como um meio de aprimorar o autocontrole do responsável pela mesma, a fim de garantir maior diligência para com o exercício do poder. ${ }^{135}$ Curiosamente, no ordenamento dos tribunais trabalhistas, a assinatura do Schöffe é requerida ( $\$ 69$ ArbGG). Além disso, há alegações de que justamente a falta de confrontação do Schöffe com a decisão por escrito e sua justificação permite que um juiz togado supere uma decisão que ele considera indesejada, através de uma sentença tão defeituosa que o sucesso de recurso, seja pelo lado da acusação ou da defesa, ${ }^{136}$ é mera formalidade. ${ }^{137}$

Sem dúvida, a isenção do Schöffe com relação à assinatura significa uma desconstrução da sua responsabilidade pela decisão final. Por outro lado, ela é consequência do papel do Schöffe como juiz dedicado principalmente à oralidade, que se encerra no momento do julgamento, e não com a formulação da sentença por escrito. ${ }^{138} \mathrm{Assim}$, devido aos problemas encontrados já com a assinatura dos juízes togados, ${ }^{139}$ é compreensível que o legislador tenha optado por uma desburocratização do processo ao prever a isenção. A decisão sobre esta questão, assim como o caso de "superação" de sentença forçada pelo juiz, é avaliada dependendo de como concebemos o juiz leigo no processo penal, e qual posição é preferível (parte 6.3). Após um breve resumo, partiremos então à análise da função e da importância do Schöffe no sistema alemão.

\section{Resumo dA situação do SCHÖFfE no PROCESSO PENAL ALEMÃo}

Os Schöffen são juízes leigos equiparados, a princípio, aos juízes togados, mas, sobretudo, são juízes somente no processo principal.

135 Ver o dever de justificação de atos administrativos no processo administrativo alemão, § 39 Verwaltungsverfahrensgesetz (Bund), v.g.

${ }^{136} \mathrm{Na}$ Alemanha, são permitidas a apelação e a revisão a favor do Ministério Público, § 296 I StPO.

137 Sobre isso, ver notas de rodapé 85 e 168.

138 Porém, ainda faz parte do processo principal, do qual o Schöffe faz parte integral.

${ }^{139}$ Sobre a assinatura ver: GREGER, Anette. Karlsruber Kommentar zur Strafprozessordnung... \$ $275 \mathrm{n}^{\circ}$ 21-37. 
O leigo, portanto, não decide sobre absolvição ou condenação por voto majoritário como o júri no Brasil, mas faz parte da deliberação do julgamento, onde o seu voto pesa como o voto do juiz. Em conjunto com outros Schöffen, ele poderia vedar uma decisão, no entanto, na prática, isto quase nunca acontece. ${ }^{140}$ Em consequência, a alegada confusão do “júri alemão" pelo fato de o canibalismo não ser punível na Alemanha, referida na introdução desse artigo, não afetaria o julgamento do caso da mesma forma como no Brasil. ${ }^{141}$ A competência do Schöffe em comparação com a competência do júri brasileiro, que é somente a de crimes dolosos contra a vida (art. 5 XXXVIII CF), é bastante ampla, desde crimes leves até graves. ${ }^{142}$ Porém, através de vários dispositivos legais e interpretações judiciárias, a posição dele como "juiz equiparado" no processo principal é enfraquecida, excluído de muitas decisões e poderes processuais. Entre outros, não presta assinatura sob o próprio julgamento. Consequentemente, parece seguro concluir que o Schöffe não influencia a jurisprudência com "o senso natural de justiça", mas segue, em toda regra, a linha do juiz togado. ${ }^{143}$

\section{Criticas e avaliação da participação do leigo no PROCESSO Penal}

A discussão acerca da participação de juízes leigos no sistema alemão e brasileiro conhece dois polos da doutrina: os prós e os contras da participação de leigos. A visão tradicionalista vê o juiz leigo como garante de um sistema democrático, não somente útil, mas até mesmo indispensável para um processo penal no Estado democrático de direito. ${ }^{144}$

${ }^{140}$ Ver acima parte 3.

${ }^{141}$ Aliás, não foi encontrado um artigo que confirmasse a alegada confusão, o que houve é preocupação com a psique dos Schöffen, que tiveram que ver o vídeo dos atos do Sr. Meiwes, http://www.faz.net/aktuell/rhein-main/region/revisionsprozess-meiwes-anwaelte-bezweifeln-zustaendigkeit-des-gerichts-1304380.html (acessado em 16.04.2014).

${ }^{142}$ Ver acima parte 3 último paragrafo.

${ }^{143}$ Assim também: DUTTGE, Gunnar. Laienrichter in der Strafgerichtsbarkeit - Anspruch und Wirklichkeit..., p. 360 ss.

${ }^{144}$ TASSE, Abdel El. Tribunal do Júri. Curitiba: Juruá Editora, 2007, p. 21. 
Esta posição é defendida especialmente no Brasil, onde a participação do juiz leigo é garantia constitucional (ver art. 5 XXXVIII CF) do réu, a qual ele, porém, não pode renunciar ${ }^{145}$. Qualquer voz que queira abolir o instituto no Brasil, portanto, visa a constituciones ferenda.

Diferentemente da situação do júri brasileiro, na Alemanha não há um debate constitucionalista sobre a competência do Schöffe, pois encontram-se normas somente em nível de lei. ${ }^{146}$ Portanto, os oponentes alemães, que somam alguns artigos nos últimos oito anos, ${ }^{147}$ têm uma posição mais forte, ao olhar positivista. A abolição da participação do leigo como Schöffe na StPO é questão de lege ferenda, que formalmente poderia ser efetuada pelo legislador federal a qualquer momento, com base no art. 74 I Nr. 1 GG - isto não levando em consideração possíveis exigências constitucionais de sua existência por outros princípios.

\subsection{ENFRENTANDO OS "tradicionalistas"}

Os argumentos pro participação do leigo no processo penal são referidos pelo autor Tasse ${ }^{148}$. Um dos argumentos parte de uma concepção de justiça material em dependência somente das circunstâncias do caso concreto: a função é justamente avaliar um caso sem exagero

145 TASSE, Abdel El. Tribunal do Júri..., p. 22. Posição dogmaticamente problemática que, porém, não aprofundaremos.

${ }^{146}$ Com exceção do art. 88 Bayrische Verfassung (Constituição do Estado da Baviera), que garante ao cidadão participar da justiça como Schöffe. Como esta norma encontra-se somente em nível de Estado da Federação (Bundesland), a efetividade desta norma frente ao ordenamento federal contemporâneo parece duvidosa, pois as leis que preveem o Schöffe como instituto, ou seja, o GVG e a StPO, são de competência federal concorrente (art. 74 I Nr.1 GG em conexão com art. 72 I GG), o que veda regulamento estadual durante a vigência do GVG e da StPO.

${ }^{147}$ DUTTGE, Gunnar. Laienrichter in der Strafgerichtsbarkeit - Anspruch und Wirklichkeit. ...; SATZGER, Helmut. Die Schöffen im Strafprozess...; VULTEJUS, Ulrich/VOLK, Klaus. Pro \& Contra: Stärkung der Rolle der Schöffen...; entre outros.

${ }^{148}$ TASSE, Abdel El. Tribunal do Júri... 
tecnicista e rigores normativos, atendendo a um desejo de justiça, não necessariamente estabelecida nos termos legais. ${ }^{149}$ Partindo deste pressuposto, os tradicionalistas defendem que a decisão tomada por leigos é mais qualificada, amalgamado com a convicção de que o legislador é incapaz de criar uma lei suficientemente precisa. Isto porque, dado que a justiça não depende de leis, mas primeiramente de um senso de justiça, o leigo, livre de doutrinamento jurista, está mais qualificado para julgar fazendo uso do seu senso puro de justiça. Dizem que não existiria justiça mais precisa que aquela na qual o próprio cidadão analisa a conduta praticada por outro integrante do corpo social e que o habitante comum da cidade sabe de forma mais clara que qualquer congressista o que é melhor para a sua vida. ${ }^{150}$ Seria impossível que o legislador conseguisse levar em consideração todos os casos possíveis em uma sociedade complexa e que está mudando rapidamente. ${ }^{151} \mathrm{Nem}$ toda lei representaria a vontade do povo. O júri seria, então, demanda democrática obrigatória. Os críticos do júri não perceberiam que se contradizem, pois todo poder vem do povo, então é ele quem deve decidir. ${ }^{152}$ Críticos do tribunal do júri seriam "críticos da própria democracia". ${ }^{153}$

Todos estes argumentos partem de concepções de justiça e sociedade opostas àquelas vigentes no Estado Democrático de Direito contemporâneo. A justiça material, objetivo dos tradicionalistas, é um conceito de enorme complexidade. ${ }^{154}$ De toda maneira, parece-nos um conceito cujo alcance está tão distante do tribunal técnico quanto do tribunal leigo. O problema não está na formação do juiz, mas sim no confronto com casos concretos cuja complexidade foge do previsto pelo legislador. Porém, esta situação é enfrentada, no Estado de Direito, através de recursos e pela jurisprudência de uma corte constitucional, que julga a excepcionalidade do caso concreto e a infração de direitos fundamentais

${ }^{149}$ TASSE, Abdel El. Tribunal do Júri..., p. 24 s.

${ }^{150}$ TASSE, Abdel El. Tribunal do Júri..., p. $22 \mathrm{~s}$.

${ }^{151}$ TASSE, Abdel El. Tribunal do Júri..., p. 23, nota de rodapé 5.

${ }^{152}$ TASSE, Abdel El. Tribunal do Júri..., p. 26.

${ }^{153}$ TASSE, Abdel El. Tribunal do Júri..., p. 23.

${ }^{154}$ Ver: TIMM, Ricardo de Souza. Justiça Em Seus Termos. Rio de Janeiro: Lumen Juris, 2010. 
do cidadão, aplicando os princípios constituintes desse mesmo Estado. $\mathrm{O}$ que é justo, no caso concreto complexo, diferentemente do que pensam os defensores ideológicos do leigo no processo penal, não é pacífico, e depende das convicções subjetivas de cada julgador. Isto em mente é que se constrói um Estado Democrático de Direito: para que haja coerência e igualdade no processo penal é importante impedir até o limite do possível que os princípios axiológicos de um ordenamento democrático de direito sejam substituídos pela vontade própria do tribunal.

Ao lado dessa questão da suposta melhor qualificação do leigo defende-se, como exposto, que o legislador não teria, também, a qualificação necessária. Neste ponto, o tradicionalista ideológico exprime um entendimento diverso do Estado Democrático de Direito, fundado sobre o princípio da divisão de poderes, pois é justamente este o vetor crucial reitor do referido modelo de Estado. A instituição eleita pelo povo é o legislador e não a banca do júri. A lei, e não a "íntima convicção" da maioria entre sete (7) jurados, ${ }^{155}$ é vontade do povo: democrática é a aplicação da lei em vigor igualmente para todos nos limites de um ordenamento democrático de direito.

Contra isto poderia se alegar que o júri não cria lei, mas é mero tribunal e, portanto, só aplica a mesma, somado com o argumento de que esta competência, já que advém de uma expressão da vontade do povo - substituída, no caso do Brasil em tese, pela constituinte - está democraticamente legitimada. Entretanto, vemos nisto uma insuperável contradição: se o papel do tribunal do júri é somente a aplicação da lei, então por que não confiar este poder a alguém que estudou, no mínimo, cinco anos e meio para isto e passou por provas difíceis para comprovar a sua aptidão? ${ }^{156} \mathrm{O}$ sistema Civil Law é predominantemente o sistema de abstração e centralismo. ${ }^{157}$ Casos excepcionais são levados à próxima

${ }^{155}$ Ver acima parte 4.1.

${ }^{156}$ DUTTGE, Gunnar. Laienrichter in der Strafgerichtsbarkeit - Anspruch und Wirklichkeit..., p. 361. Claro que há elementos que justificam a participação do leigo mesmo assim, como veremos mais abaixo.

157 Subsumido à descrição de DAMASKA, Mirjan R. Las caras de la justicia y El poder Del estado. Santiago de Chile: Editorial Jurídica de Chile, 2000 (1986 Yale University). 
instância e assim julgados por todos. Os defensores polêmicos do tribunal do júri não levam em conta, por sua vez, que o resultado sistêmico que buscam é a imprevisibilidade do julgamento leigo, a insegurança jurídica e, por consequência, a infração do primado da lei: o poder do judiciário acima do poder legislativo já na primeira instância. Querem para si, em suas funções de defesa ou acusação, o poder de convencer sete (7) pessoas a se opor à vontade expressa pelo povo na eleição do legislativo. A decisão democrática do povo tem os seus limites no princípio do Estado de Direito e as suas expressões chamadas direitos fundamentais: entre eles, o direito à igualdade perante a lei, na Alemanha previsto no art. 3 GG. A participação de leigos no poder judicativo infringe este princípio quando, por razões ideológicas, permitimos uma corte arbitrária, expressamente emancipada do primado da lei.

\subsection{ENFRENTANDO OS ABOLICIONISTAS}

Os abolicionistas, por outro lado, colocam em questão a alegação de qualquer efeito democrático e legitimador da participação do Schöffe. Chamam-no de romantismo social, deslocado da realidade. Simplesmente não haveria efeitos positivos que valeriam os custos financeiros altos. ${ }^{158}$ Perguntam: por que o cirurgião não opera com leigos, se os efeitos da participação destes são tão positivos em trabalhos técnicos? ${ }^{159}$ Contra isso, fácil opor que um julgamento penal é algo que afeta não somente o acusado, mas a comunidade como um todo também. ${ }^{160} \mathrm{O}$ juiz, diferentemente do cirurgião, não aplica a medicina (certamente mais exata que o direito) mas a lei, a força pública. Além disso, como sabemos, o cirurgião não é penalmente responsável

${ }^{158}$ Entre outros: DUTTGE, Gunnar. Laienrichter in der StrafgerichtsbarkeitAnspruch und Wirklichkeit..., p. 362 s.

${ }^{159}$ FÖHRIG, Friedrich-Karl. Kleines Strafrichter-Brevier. München: Verlag C.H. Beck, 2008, p. 88.

${ }^{160}$ Esse elemento social na Alemanha se reflete, por exemplo, no proferimento público da sentença "em nome do povo" (§ $268 \mathrm{I}$ StPO). Para mais réplicas a esta questão, ver BÖRNER, René. Die Beteiligung von Laienrichtern am Strafprozess..., p. 435 ss. 
somente por dolo, situação confortável na qual o juiz se encontra ( $\$ 339$ StGB - Prevaricação). Sendo assim, alguma forma de fiscalização dessa função pública é prudente.

Os abolicionistas observam que a ideia de que precisamos de "bom senso" através dos leigos significaria que o mesmo estaria ausente no juiz togado e isto seria um "ehrabschneidendes Vorurteil", um preconceito difamatório. ${ }^{161}$ Sobretudo para a nova geração de juízes, fortemente identificada como "democrata". Ora, é justamente esta tendência de superestimar a própria neutralidade e a infalibilidade democrática que exige ceticismo para com a exclusão total de leigos do processo penal. Na Alemanha, vemos sinais desta tendência perigosa. Os juízes veem-se como justos e razoáveis, democratas de uma nova geração que não enxergam a razão de ser de garantias processuais que protegem o acusado do poder judicial. ${ }^{162}$ Além disso, há pesquisas também no Brasil que mostram que o juiz, em grande parte, não só reconhece a falta de neutralidade da sua atuação, como considera este caminho de parcialidade parte do seu papel sistêmico. ${ }^{163}$

\subsection{Posicionamento}

Como então posicionar-se frente à participação de leigos no processo penal? Certamente argumentos polêmicos a favor da participação do leigo como que os adversários teriam o "germe do autoritarismo" 164 não sustentam a existência da participação leiga de lege lata

${ }^{161}$ DUTTGE, Gunnar. Laienrichter in der Strafgerichtsbarkeit - Anspruch und Wirklichkeit..., p. 361.

${ }^{162}$ Situação descrita por BÖRNER, René. Die Beteiligung von Laienrichtern am Strafprozess..., p. 434.

${ }^{163}$ Veja sobre a falta de neutralidade dos juízes brasileiros: PINHEIRO, Armando Castelar. Judiciário, reforma e economia: a visão dos magistrados. Febraban, Dezembro de 2002, p. 6, disponível em http://www.febraban.org. br/Arquivo/Destaques/armando_castelar_pinheiro2.pdf.

${ }^{164}$ TASSE, Abdel El. Tribunal do Júri..., p. 25. Respondo: O "germe do adversário" é o primado da lei, "filhote" do princípio do Estado de Direito e do princípio da Democracia. 
nos ordenamentos alemão e brasileiro. No Estado de direito vigem o primado da lei e a igualdade perante a mesma, o que exige o mesmo direito para todos os réus. Em consequência, a aplicação da lei, que já passou por legitimação democrática no Estado de Direito, não pode depender de núcleos leigos, mas deve, sim, ser executada por juízes técnicos estudiosos dessa mesma lei, anteriormente legitimada democraticamente pelo legislativo. Como acabamos de ver, é justamente isto que, mesmo com várias incoerências e falhas, no sistema do Schöffe, acaba acontecendo: a influência do voto do Schöffe na decisão é mínima e é o juiz togado que conduz a decisão. ${ }^{165}$ Contudo, mesmo que o Schöffe tenha pouca influência direta no resultado do processo, há algo a favor da participação leiga que os abolicionistas não levam em consideração: o efeito de contenção reforçado pelo discurso.

O processo penal é um processo de comunicação ${ }^{166}$ e, por isso, o colóquio de deliberação é importante. Os Schöffen acrescentam juízes e assim forçam pelo julgamento por voto (e não por um juiz somente) o debate sobre a decisão. ${ }^{167}$ Ainda que o juiz togado possa, mesmo que ilicitamente, forçar a superação da sentença facilitando o recurso, ${ }^{168} \mathrm{o}$ mero perigo de se colocar nesta situação força uma contenção frente

${ }^{165}$ Quase poderíamos chamar este sistema "hierarquista legalista lógico" na terminologia de DAMASKA, Mirjan R. Las caras de la justicia..., p. 42, já que se trata de um sistema processual onde julgamentos são feitos por funcionários profissionalizados, no qual a decisão é avaliada pela fidelidade à norma aplicável, menos individualizada, mas mais consistente. Porém, um tal sistema tem várias desvantagens, e também nunca se encontra em estado puro ( $\mathrm{p}$. 413 s.). Buscamos sim a consistência, ou seja, igualdade, que é um princípio de valor caro em uma sociedade desigual, mas sem restringir demasiadamente uma flexibilização constitucional necessária.

${ }^{166}$ BÖRNER, René. Die Beteiligung von Laienrichtern am Strafprozess... p. 436 ss. ${ }^{167}$ BÖRNER, René. Die Beteiligung von Laienrichtern am Strafprozess..., p. 437 ss; de forma semelhante LOPES JR., Aury. Direito Processual Penal e sua Conformidade Constitucional. Vol. II. 4a edição. Rio de Janeiro: Lumen Juris, 2010. p. 328, que atribui ao escabinato um efeito positivo na administração da justiça através do intercambio de saberes.

${ }^{168}$ Ver nota de rodapé 85 e 137 . Uma situação bastante séria, que, se realmente ocorrer, ao nosso olhar, somente reforça os argumentos a favor do controle dos juízes togados. 
aos Schöffen. A visão leiga também pode enriquecer o debate sobre a sentença, e segundo Vultejus ${ }^{169}$, é devido à presença deles que se dá a inteligibilidade do Amtsgericht e do Landgericht e devido à ausência deles a ininteligibilidade do Oberlandesgericht. Mesmo que isto seja exagerado, um efeito positivo na inteligibilidade das decisões nos parece mais provável com a participação do leigo do que sem ela.

A condenação e a absolvição demandam transparência. É, por isso, também que o juiz togado fundamenta e assina a sentença, e tendo em vista o papel do leigo no processo penal podemos agora precisar a questão acerca da necessidade do juiz leigo de assinar a sentença: $\mathrm{O}$ fato do Schöffe não assinar a mesma é discutível. Todavia, o mais importante é a introdução de estranhos no aparelho jurídico, sempre novos a cada cinco anos. ${ }^{170}$ Por que não

(..) devam ser formados colégios mistos, nos quais os leigos, como mostra a experiência, costumam exercer influência inferior à dos juristas profissionais, de tal modo que sua presença tem na prática, quase sempre apenas, a significação de uma espécie de caráter público obrigatório das discussões dos juristas profissionais $(\ldots)^{171}$ ?

Este caráter público é levado em consideração pela publicidade do processo penal também. ${ }^{172}$ Porém, muito mais que este instituto, que hoje em dia é posto em uso principalmente pela mídia, o juiz leigo está por trás da deliberação de sentença e participa da "barganha" de forma imediata. Não subestimaremos o efeito levemente pressionador de contenção que a presença de estranhos, que têm o poder de vedação, mesmo que somente na teoria, tem nos atores técnicos.

${ }^{169}$ VULTEJUS, Ulrich/VOLK, Klaus. Pro E Contra: Stärkung der Rolle der Schöffen..., p. 63.

${ }^{170}$ Ressaltado por BÖRNER, René. Die Beteiligung von Laienrichtern am Strafprozess..., p. 438.

${ }^{171}$ WEBER, Max. Economia e sociedade. Fundamentos da Sociologia Compreensiva (1921/1922). Brasília: Editora Universidade de Brasilia, Volume 2, 1999, p. 152.

${ }^{172}$ A publicidade do processo tem fundamentos no princípio do Estado de Direito, e hoje se dá atendendo ao interesse de informação da coletividade, VOLK, Klaus. GRUNDKURS StPO..., p. 178 (§ 18 Rn. 27). 
O que o Schöffe traz é ventilação para um sistema que, justamente por não querer ser incomodado, se torna suspeito. ${ }^{173} \mathrm{O}$ mais importante, portanto, é que ele está presente para observar: “(...) o modelo atual da presença e participação de leigos no processo principal e na deliberação de sentença (efetua) um contributo significativo para a confiança geral de que no processo penal, nada de indevido esteja acontecendo". ${ }^{174}$

\section{Considerações Finais}

O sistema alemão de participação de leigos é um sistema de escabinato, ou seja, o leigo é juiz (chamado de Schöffe) e não há uma divisão de papeis comparável ao júri brasileiro. A eleição, as qualidades para ser eleito como Schöffe, assim como o seu papel e as suas competências encontram-se fortemente regulamentados (parte 2. a 4.). Enquanto, em tese, o Schöffe tem o mesmo peso que o juiz togado, na prática ele não o tem (parte 4 e 5). Porém, isso está, não obstante alguns problemas levantados, de acordo com o Estado Democrático de Direito, pois o juiz leigo não garante o "povo decidindo" e nem deve garanti-o (parte 6.). No Estado Democrático de Direito, pelo vigor do primado da lei, os direitos constitucionais são garantidos através de recursos num devido processo penal, que tem como fim a aplicação

${ }^{173}$ BÖRNER, René. Die Beteiligung von Laienrichtern am Strafprozess ..., p. 434, alerta para os perigos advindos da nova autoimagem como "democrata" do juiz contemporâneo que, justamente por se entender como justo e neutro, não vê mais razão para demasiados direitos processuais para a defesa.

174 “(...) die heutige Form der Anwesenheit und Beteiligung von Laien an der Hauptverhandlung und der Urteilsberatung (leistet) einen wesentlichen Beitrag zu einem allgemeinen Vertrauen darauf, dass es im Strafprozess mit rechten Dingen zugeht": BÖRNER, René. Die Beteiligung von Laienrichtern am Strafprozess..., p. 436. Um argumento a favor desta afirmação é algo que até um abolicionista como DUTTGE, Gunnar. Laienrichter in der Strafgerichtsbarkeit - Anspruch und Wirklichkeit..., p. 362, teve que admitir: Os Schöffen estão em geral muito satisfeitos com a sentença proferida e com a imparcialidade do processo. 
da lei fruto da legislação democrática, nos limites da constituição. $\mathrm{O}$ juiz leigo assume o papel de contribuir, assegurando e fortalecendo os princípios vigentes, como por exemplo, a oralidade e imediatidade. ${ }^{175}$ Eles têm justamente o papel de controle e não de ser equiparados ao juiz, contrário ao raciocínio na doutrina176 e do proclamado no $\$ 30$ I GVG, só para ser depois relativizado, como vimos, por vários outros dispositivos da lei e da jurisprudência

Contudo, precisamos dos leigos para monitorar o processo penal, para não nos tornarmos um sistema despreocupado com a sua inteligibilidade e transparência. Ao invés de celebrar com grandes palavras o júri, que no caso do Brasil julga somente crimes dolosos contra a vida, devíamos pensar em mais competência para juízes leigos nos mais variados casos, que não passam por cima da lei democrática julgando somente pela consciência, mas são incluídos na tomada de decisões judiciais e, assim, monitoram os juízes técnicos na devida aplicação da lei: “(...) neste regulamento as forças diversas se aproximam de forma natural às funções às quais correspondem (...)”. ${ }^{177}$

Certamente os dois sistemas vigentes têm as suas falhas e incoerências, e devem ser aprimorados para conferir ao processo a estabilidade e continência adequada. No entanto, a participação de leigos sem outorgá-los todo o poder de decisão parece um caminho muito viável para alcançar estas demandas de um Estado Democrático de Direito moderno que queremos ser.

175 Por isso, estamos com Börner quando proclama que a conferição dos autos pelos Schöffen deve ser a exceção, ver BÖRNER, René. Die Beteiligung von Laienrichtern am Strafprozess..., p. 439.

${ }^{176}$ SATZGER, Helmut. Die Schöffen im Strafprozess..., p. 523.

177 “(...) bei dieser Regelung neigen sich die verschiedenen Kräfte in natürlicher Weise den Aufgaben zu, die ihnen entsprechen (...)", MAYER, Max Ernst. Rechtsnormen und Kulturnormen (1903). Darmstadt: Wissenschaftliche Buchhaltung, 1965, p. 100, a favor do sistema Schöffe. 


\section{REFERÊNCIAS}

ANGER, Thorsten. Die Verfassungstreuepflicht der Schöffen. Neue Juristische Wochenschrift, 2008, p. 3041.

BADER, Johann. Die Kopftuch tragende Schöffin. Neue Juristische Wochenschrift, 2007, p. 2964.

BARTHE, Christoph. Karlsruher Kommentar zur Strafprozessordnung. München: Verlag C.H. Beck, 7. Auflage 2013.

BÖRNER, René. Die Beteiligung von Laienrichtern am Strafprozess als Erkenntnismitteleinerfunktionellen Theorie des Strafprozessrechts. Strafverteidiger Forum, 11/2012, p. 434.

DAMASKA, Mirjan R. Las caras de la justicia y El poder Del estado. Santiago de Chile: Editorial Jurídica de Chile, 2000 (1986 Yale University).

DAWSON, John P. A History of Lay Judges. Cambridge, Massachusetts: HARVARD UNIVERSITY PRESS, 2010 (1960).

DEHN, Bertram. Besetzung bei Entscheidung außerhalb der Hauptverhandlung. Neue Zeitschrift für Strafrecht, 1997, p. 606.

DUTTGE, Gunnar. Laienrichter in der Strafgerichtsbarkeit - Anspruch und Wirklichkeit. Juristische Rundschau, Heft 9/2006, p. 358.

FÖHRIG, Friedrich-Karl. Kleines Strafrichter-Brevier. München: Verlag C.H. Beck, 2008.

GERICKE, Jan. Karlsruher Kommentar zur Strafprozessordnung. München: Verlag C. H. Beck, 7. Auflage 2013.

GIACOMOLLI, Nereu José. A fase preliminar do processo penal. Rio de Janeiro: Lumen Juris, 2011.

GREGER, Anette. Karlsruher Kommentar zur Strafprozessordnung. München: Verlag C.H. Beck, 7. Auflage 2013.

GROH, Kathrin. Angewandte Verfassungsrechtsprechung? - Die Schöffin mit Kopftuch. Neue Zeitschrift für Verwaltungsrecht, 2006, p. 1023. 
JAHN,Matthias/MÜLLER,Martin. Das Gesetz zur Regelung der Verständigung im Strafverfahren - Legitimation und Reglementierung der Absprachenpraxis. Neue juristische Wochenschrift, 2009, p. 2625.

LOPES JR., Aury. Direito Processual Penal e sua Conformidade Constitucional. Vol. II. 4a edição. Rio de Janeiro: Lumen Juris, 2010. p. 328.

MAYER, Max Ernst. Rechtsnormen und Kulturnormen (1903). Darmstadt: Wissenschaftliche Buchhaltung, 1965.

MOSBACHER, Andreas. Aktuelles Strafprozessrecht. Juristische Schulung, 8/2011, p. 708.

PACELLI DE OLIVEIRA, Eugênio. Curso de processo penal. Rio de Janeiro: Lúmen Júris, $10^{\circ}$ edição, 2008.

PINHEIRO, Armando Castelar. JUDICLÁRIO, REFORMA E ECONOMIA: A VISÃO DOS MAGISTRADOS. Febraban, Dezembro de 2002. Link: http://www.febraban.org.br/Arquivo/Destaques/armando_castelar_pinheiro2.pdf

PRÜTTING, Hanns. Germelmann/Matthes/Prütting, Arbeitsgerichtsgesetz Kommentar. München: Verlag C.H. Beck, 8. Auflage 2013.

SANDEL, Michael J. JUSTIÇA O que é fazer a coisa certa. Rio de Janeiro: Civilização Brasileira, 2012.

SATZGER, Helmut. Die Schöffen im Strafprozess. Juristische Ausbildung, Heft 7/2011, p. 518.

SCHÜNEMANN, Bernd. Ein deutsches Requiem auf den Strafprozess des liberalen Rechtsstaats. Zeitschrift für Rechtspolitik, 2009, p. 104.

SCHÜNEMANN, Bernd. Der Richter im Strafverfahren als manipulierter Dritter? Zur empirischen Bestätigung von Perseveranz- und Schulterschlussefekt. Strafverteidiger (Zeitschrift), 2000, p. 159.

TASSE, Abdel El. Tribunal do Júri. Curitiba: Juruá Editora, 2007.

TIMM, Ricardo de Souza. Justiça Em Seus Termos. Rio de Janeiro: Lumen Juris, 2010. 
VASCONCELLOS, Vinicius G; GALÍCIA, Caíque Ribeiro. Tribunal do júri na justiça criminal brasileira: críticas e propostas de reforma para a restituição de sua função de garantia no processo penal democrático. Revista Eletrônica de Direito Processual, vol. 13, p. 903-929, 2014.

VOLK, Klaus. GRUNDKURS StPO. München: Verlag C.H. Beck, 2008.

VULTEJUS, Ulrich/VOLK, Klaus. Pro E Contra: Stärkung der Rolle der Schöffen. Zeitschrift für Rechtspolitik, Heft 02/2004, p. 63.

WEBER, Max. Economia e sociedade. Fundamentos da Sociologia Compreensiva (1921/1922). Brasília: Editora Universidade de Brasília, Volume 2, 1999.

\section{Como CitAR ESte ARTIGo:}

MOELLER, Uriel. O "Júri" Alemão: O leigo no processo penal na Alemanha. Revista Brasileira de Direito Processual Penal, Porto Alegre, vol. 2, n. 1, p. 59 - 98, 2016. http://dx.doi.org/10.22197/rbdpp.v2i1.17 